\title{
Jan Kochel. Wprowadzenie do edukacji osób starszych. W kręu pedagogiki katolickiej. Opole: Redakcja Wydawnictw Wydziału Teologicznego Uniwersytetu Opolskiego, 2020, ss. 212.
}

DOI: http://dx.doi.org/I0.12775/PCh.2020.029

Monografia - jak wskazuje tytuł - stanowi wprowadzenie do edukacji osób starszych, a właściwie do geragogiki, której edukacja osób starszych jest przedmiotem. Podejmowana w książce problematyka, wobec demograficznego zjawiska starzenia się społeczeństwa, jest dziś bardzo aktualna. Zagadnienia edukacji, formacji, a nawet duszpasterstwa osób starszych zostały w zamyśle autora opracowane z perspektywy pedagogiki katolickiej. Praca składa się z wprowadzenia, czterech rozdziałów, zakończenia, bibliografii (podzielonej na zbiór dokumentów Kościoła, literaturę przedmiotu, literaturę pomocniczą i netografię) oraz streszczenia w języku angielskim. Ponadto w zakończeniu każdego rozdziału zamieszczono wybrane teksty źródłowe, repertorium oraz najważniejszą bibliografię dotyczącą omawianych zagadnień.

Wprowadzenie do książki informuje czytelnika o sposobie rozumienia w niej starości, która nie będzie postrzegana jedynie przez pryzmat nieuniknionych zmian biologicznych dokonujących się w człowieku, lecz przede wszystkim będzie analizowana z perspektywy metafizycznej, antropologicznej i teologicznej, ponieważ ten okres życia osoby stawia ją ,w obliczu najistotniejszych problemów i najważniejszych pytań: o istotę, sens i cel życia" (s. 5). Po skrótowym omówieniu kolejnych rozdziałów monografii, we wprowadzeniu został zdefiniowany termin ,aktywne starzenie się” (ang. usual aging). Następnie podkreślono potrzebę interdyscyplinarnego podejścia do zagadnień gerontologicznych, zauważając w tym obszarze ,brak [...] opracowań interdyscyplinarnych z pogranicza pedagogiki i teologii” (s. 8-9). Ten brak mają zapełnić analizy dokonywane z perspektywy pedagogiki katolickiej, która - zdaniem autora - „może sugerować konfesyjne ujęcie [rozważanej problematyki], lecz w praktyce jest próbą uświadomienia, że pedagogika katolicka ma swoją antropologię - naukę o człowieku, teleologię naukę o celach bytu oraz aksjologię - naukę o wartościach" (s. 9). Autor odwołał się przy tym do artykułu Radosława Chałupniaka (2017), w którym pedagogika katolicka jest traktowana - właśnie ze względu na konfesyjnie rozumianą antropologię, teleologię, a przede wszystkim aksjologię - jako „uściślenie” pedagogiki chrześcijańskiej (tamże, s. 66), choć należy zauważyć, że ze względu na tradycje uprawiania refleksji pedagogicznej inspiro- 
wanej religią chrześcijańską czy wyznaniem katolickim, nie jest to jedyny model relacji pomiędzy pedagogiką chrześcijańską a pedagogiką katolicką. Ostatecznie jednak refleksje zaprezentowane w monografii są zgodne z metodologicznymi założeniami klasyków polskiej pedagogiki katolickiej, którzy definiowali ją jako ,system naukowy wychowania i nauczania nie tylko zupełnie zgodny z teologią i filozofią chrześcijańską, ale ściśle z nimi związany i wysnuwający w ich świetle, $z$ doświadczenia wychowawczego, swe zasady" (Woroniecki, 1961, s. 13), a jej podstaw szukali w doktrynie wychowawczej Kościoła katolickiego i w założeniach światopoglądowych katolickiego wychowania (zob. Kunowski, 1958, s. 296; 1959, s. 239). Rozważania zawarte w monografii zostały przedstawione przy zastosowaniu mało znanej w naukach społecznych „,metody analityczno-syntetycznej literatury pedagogicznej i teologicznej” oraz „metody porównawczej, ponieważ dzięki niej możliwe stało się rozróżnienie, co jest unikalnym wkładem formacji duchowej w dynamicznie rozwijającą się edukację senioralną" (s. 10). W istocie zastosowano metodę analizy i krytyki piśmiennictwa opisywaną już przez Józefa Pietera (1975, s. 103). Warto także zasygnalizować, że w pedagogice zestawienie czynności badawczych obejmujących „analizę, porównanie i syntezę stanowisk [...], których celem jest uchwycenie nie tylko następstwa zdarzeń i ich dynamiki, ale także tego, co jest względnie trwałym czy uniwersalnym [wniknięciem] w świat idei”, bywa charakterystyczne dla metod historiografii edukacyjnej, włączającej w swoje procedury badawcze metody hermeneutyczne, „dzięki czemu przedmiotem badań są nie tylko proste zjawiska (fakty), ale także ukryte założenia i sensy oraz wynikające z nich konsekwencje" (Sztobryn, 2010, s. 302-303).

Rozdział pierwszy, noszący tytuł „Podstawowe założenia edukacji osób starszych", podejmuje zagadnienia: podstaw gerontologii, granic starości w perspektywie życia ludzkiego, celu, zadań i treści edukacji osób starszych, roli motywacji dorosłych do uczenia się i samowychowania oraz potrzeby formacji człowieka w perspektywie celu ostatecznego. W lekturze tego rozdziału przydatna okazuje się wskazówka zawarta w podtytule książki, gdyż $\mathrm{w}$ analizach zamieszczonych w tej części monografii, obok tekstów z dziedziny pedagogiki (pedagogiki ogólnej, andragogiki, dydaktyki i innych), niejednokrotnie znaleźć można odwołania do tekstów biblijnych i ich komentarzy, do oficjalnego nauczania Kościoła, do studiów i refleksji teologicznych (w tym katechetycznych) oraz literatury ascetycznej. Dużym atutem tego rozdziału jest przywołanie bardzo wielu tekstów źródłowych dotyczących starości. Czytelnik może jednak poczuć potrzebę dalszych poszukiwań źródeł, gdyż zaraz po szczegółowej analizie pism Platona i Arystotelesa oraz pisarzy 
wczesnochrześcijańskich - św. Ambrożego i św. Jana Chryzostoma, następuje omówienie poematów Marcina Bielskiego (ok. 1495-1575) i Mikołaja Reja (1505-1569), a następnie adhortacji apostolskiej papieża Franciszka Amoris laetitia o miłości w rodzinie.

Rozdział drugi, zatytułowany „Osoby w podeszłym wieku w perspektywie biblijnej", stanowi gruntowne studium tekstów Pisma św. odnoszących się do starości. Po ogólnym zasygnalizowaniu postrzegania starości przez autorów ksiąg biblijnych (zwłaszcza tak zwanych ksiag dydaktycznych, tu: Księgi Psalmów, Księgi Przysłów, Księgi Koheleta, Księgi Mądrości i Księgi Syracha), omówione zostały ,,portrety szlachetnych starców, wzorce osobowe zarówno ze Starego, jak i Nowego Testamentu" (s. 72). Przeanalizowane zostały opisy życia takich postaci, jak: Tobiasz, Eleazar, Hiob i Noemi (ze Starego Testamentu) oraz Symeona, Anny, św. Pawła oraz św. Jana (z Nowego Testamentu). Dodatkowo umieszczono analizy dotyczące osoby „starszego" $(\pi \rho \varepsilon \sigma \beta u ́ \tau \varepsilon \rho \circ \varsigma)$ - jego funkcji i miejsca w strukturze Kościoła - w początkach powstawania wspólnot chrześcijańskich. Zamiarem autora monografii było zastosowanie ,metody interpretacji i aktualizacji przesłania biblijnego”, aby na tej podstawie ,wskazać na wybrany aspekt kerygmatyczny” (s. 72). Należy przyznać, że sama metoda lektury Biblii, zaproponowana w monografii, jest we współczesnej teologii niezwykle aktualna (zob. Kamieński, 2016). Do najważniejszych wniosków płynących z analiz tego rozdziału zaliczyć można podkreślenie optymistycznej i pozytywnej wizji starości oraz roli osób starszych w przekazywaniu wartości.

Rozdział trzeci poświęcony jest rekonstrukcji tak zwanej ,„pedagogii dojrzałości” dokonanej na podstawie pism kardynała Carla Martiniego (1927-2012). Dojrzałość tę rozumie się tu w znaczeniu integracji osoby we wszystkich sferach jej życia, zwłaszcza w sferze intelektualnej, emocjonalnej i duchowej. Fundamentem takiej dojrzałości ma być formacja duchowa, która w przypadku kard. C. Martiniego dokonywała się poprzez studiowanie tekstów biblijnych i powołanie realizowane w atmosferze duchowości ignacjańskiej. W omawianym rozdziale wskazano najpierw na podstawy pedagogii kard. C. Martiniego, które znaleźć można w tekstach biblijnych i współczesnym nauczaniu Kościoła. Następnie analizie poddano problem dorosłości w kontekście wiary człowieka i jego życia religijnego. Wskazano na zjawisko tak zwanych dorostych rozdartych i dorostych - uprzywilejowanych $w$ duszpasterstwie. Prezentując teologię nauczania $i$ wychowania $w$ wierze autorstwa kard. C. Martiniego, opisano cechy charakteryzujące jego program edukacyjny oraz specyficzne „metody”, którymi „Bóg prowadzi swój lud” (s. 127). Tę część analiz wyróżnia specyficznie teologiczny język, a źródła do nich 
stanowią zasadniczo publikacje teologiczne i ascetyczne. Podsumowując ten rozdział, autor monografii wskazał na potrzebę budowania teologii nauczania i wychowania (teologii edukacji) jako subdyscypliny, „która wciąż poszukuje swojego miejsca wśród nauk pedagogicznych" (s. 142).

Ostatni, czwarty rozdział, nosi tytuł „Formacja osób w podeszłym wieku" i ma być próbą wypracowania praktycznych wskazówek przydatnych do dalszego rozwoju ludzi starszych. Zaproponowano prowadzenie tych działań $\mathrm{w}$ trzech kierunkach podejmowanych integralnie i wpisujących się w proces osiągania „pełnej dojrzałości” przez osobę. Są nimi: formacja intelektualna, formacja społeczno-kulturowa oraz duchowa, realizowana w pracy duszpasterskiej. Z perspektywy dotychczasowej wiedzy geragogicznej ciekawe wydają się opisy formacji intelektualnej i społeczno-kulturowej ze względu na fakt powiązania znanych w tych obszarach dotychczasowych badań $\mathrm{z}$ treściami teologicznymi oraz z aktualną praktyką edukacyjną na rzecz osób starszych. W tym kontekście można zgodzić się z autorką recenzji wydawniczej książki ks. prof. Jana Kochela - s. dr hab. Anną Walulik, prof. AIK, że „publikacja [ta] może ubogacić i skierować na nowe tory myślenia przedstawicieli gerontologii, [a] za potrzebą pochylenia nad tymi problemami przemawia przede wszystkim cel stawiany przed tą dziedziną wiedzy: afirmacja i unaocznienie osobowej godności człowieka przynależnej mu w toku całego życia, w tym również w okresie przeżywania własnej starości" (Walulik, 2020).

Leszek Waga*

ORCID: 0000-0002-2159-5950

Opole, Poland

\section{Bibliografia}

Chałupniak, R. (2017). Pedagogika katolicka - znaczenie i aktualność w kontekście chaosu wartości (perspektywa polska). Studia Pastoralne, 13, 62-73.

Kamieński, Ł. (2016). Aktualizacja Pisma Świętego według dokumentu Papieskiej Komisji Biblijnej „Interpretacja Biblii w Kościele” jako nowy sposób odniesienia słowa Bożego do życia. Ruch Biblijny i Liturgiczny, 69(3), 197-215.

* Ks. dr Leszek Waga, Katedra Teologii Pastoralnej, Katechetyki, Pedagogiki i Psychologii, Wydział Teologiczny Uniwersytetu Opolskiego, Polska; e-mail: lwaga@uni.opole.pl. 
Kunowski, S. (1958). O potrzebie naukowego wyodrębnienia współczesnej pedagogiki katolickiej. Katecheta 4, 285-296.

Kunowski, S. (1959). Teologia a potrzeby pedagogiki katolickiej. Ateneum Kapłańskie, 51(1-3), 233-245.

Pieter, J. (1975). Zarys metodologii pracy naukowej. Warszawa: Państwowe Wydawnictwo Naukowe.

Sztobryn, S. (2010). Historiografia edukacyjna i jej metodologia. Wybrane zagadnienia. W: S. Palka (red.), Podstawy metodologii badań w pedagogice (s. 295-307). Gdańsk: Gdańskie Wydawnictwo Pedagogiczne.

Walulik, A. (2020). Z recenzji wydawniczych. Pobrano 6 listopada 2020 z: http:// www.ssb24.pl/warto_przeczytac,311.

Woroniecki, J. (1961). Program pedagogiki integralnej. W: tenże, Wychowanie człowieka. Pisma wybrane (s. 11-29). Kraków: Wydawnictwo Znak.

\section{Agnieszka Paczkowska. Dziecko i nastolatek w żałobie. Rola pedagogów i nauczycieli. Gdańsk: Wydawnictwo Fundacji Hospicyjnej, 2019, ss. 128.}

DOI: http://dx.doi.org/10.12775/PCh.2020.030

Z zaciekawieniem przejrzałem, a potem uważnie przeczytałem praktyczne, a jednocześnie oparte na solidnej wiedzy i doświadczeniu klinicznym, wskazania recenzowanej monografii autorskiej Agnieszki Paczkowskiej, od wielu lat pracującej jako psycholog w gdańskim Hospicjum im. ks. E. Dutkiewicza SAC. Dobrze, że lata praktyki z pacjentami i osieroconymi dziećmi i młodzieżą udało się tak ciekawie przełożyć na dzieło, będące kolejną publikacją z serii Biblioteki Tumbo Pomaga wydawanej przez Fundację Hospicyjną (www.fundacjahospicyjna.pl). Składają się na nie: wprowadzenie, cztery rozdziały, zakończenie i dodatki oraz bibliografia. Każdą z części zamyka praktyczna ramka podsumowująca w skrócie omawianą tematykę. Dzięki temu całość jest przejrzysta i czytelna. Spełnia funkcję poradnika dla praktyków - pedagogów i psychologów szkolnych, nauczycieli i wychowawców, do których głównie jest adresowana, ale stanowi także źródło solidnej wiedzy naukowej, co potwierdza rozbudowany aparat krytyczny z przypisami, do których mogą sięgnąć szczególnie studenci, nauczyciele akademiccy i badacze przedstawianych zagadnień. 